\title{
ANTIPATERNALIZAM I VIŠESTRUKO PRAVO GLASA U MILLOVOJ POLITIČKOJ FILOZOFIJI ${ }^{1}$
}

\author{
Ivan Cerovac \\ Sveučilište u Rijeci \\ Filozofski fakultet
}

\begin{abstract}
SAŽETAK
Prigovor nekonzistentnosti koji se ponekad upućuje političkoj filozofiji J. S. Milla poprima različite oblike, a u ovom se radu obrađuje slučaj nekonzistentnosti između antipaternalizma izraženog u O slobodi i paternalističkog opravdanja demokracije i prijedloga višestrukog prava glasa u Razmišljanjima o predstavničkoj vlasti. Rad polazi od karakterizacije Milla kao demokratskog instrumentalista, te ističe kako Millovo opravdanje edukativne uloge demokracije i epistemičke vrijednosti višestrukog prava glasa ne mora biti utemeljeno na paternalističkim idejama. Povezivanjem Millove teze, kako država može intervenirati u slobodu pojedinca kada čini neku radnju kojom krši dužnost koju ima prema drugima, s Estlundovom idejom političkog opravdanja putem normativnog pristanka rad pokazuje kako Millovo opravdanje demokracije (i višestrukog prava glasa) može biti utemeljeno na dužnostima koje imamo prema drugima, a ne na paternalizmu.
\end{abstract}

KLJUČNE RIJEČI: paternalizam, višestruko pravo glasa, normativni pristanak, demokratski instrumentalizam, epistemička demokracija, Mill, Arneson, Estlund

John Stuart Mill autor je brojnih, i danas relevantnih, argumenata i ideja unutar moralne i političke filozofije. ${ }^{2}$ Millov bogati opus često predstavlja polaznu točku brojnih suvremenih društveno-političkih rasprava: od pitanja zabrane cenzure i govora mržnje, te ograničenja paternalističkih

1 Ovaj rad je izrađen u sklopu projekta „Dobrobit, pripadnost i društvena pravednost“ (UIP2017-05-3462), koji je sufinancirala Hrvatska zaklada za znanost.

2 Velik dio ovog rada rezultat je izrazito korisnih savjeta, kritika i pitanja postavljenih u sklopu ljetne škole "Equality and Citizenship", održane u srpnju 2017. na Sveučilištu u Rijeci. Želio bih posebno zahvaliti Richardu Arnesonu, Davidu Milleru, Leifu Wenaru, Elviju Baccariniju i Nebojši Zeliču, čiji su vrijedni komentari značajno obogatili i oblikovali ovaj rad. 
politika države, do uloge stručnjaka u političkome odlučivanju i ograničenja vlasti demokratske većine. Zbog svoje izuzetne širine i raznolikosti tema koje obrađuje, kao i zbog preko 50 godina aktivnog publiciranja Millova se politička i moralna filozofija ponekad kritizira zbog nedostatka konzistentnosti i povezanosti. Jedna od zanimljivijih i razornijih kritika svakako je i ona koja poručuje kako Mill ne iskazuje jedinstven i konzistentan stav prema paternalizmu u svojim djelima O slobodi i Razmišljanja o predstavničkoj vlasti. Naime, neki autori (Arneson 1982; Brink 2013) smatraju kako Millovo čvrsto osuđivanje paternalizma, naglašavano u raspravama o slobodi, nije kompatibilno s opravdanjem višestrukoga prava glasa u procesima izbora političkih predstavnika. Ako davanje višestrukoga prava glasa bolje obrazovanim građanima opravdamo intelektualnim i moralnim unapređenjem građana, te kvalitetom odluka koje će predstavničko političko tijelo donositi (na dobrobit cijele političke zajednice), uvodimo paternalističke ideje kojima ograničavamo slobodu izbora (kolektivni suverenitet) političke zajednice i činimo to upravo za unapređenje dobrobiti te političke zajednice. Mill treba pokazati kako postoji neka relevantna razlika između političkog odlučivanja (u kojemu su neki oblici paternalizma, manifestirani kroz višestruko pravo glasa i ograničavanje vlasti većine, prihvatljivi) i privatnog odlučivanja (u kojemu je svaki oblik paternalizma, pretpostavimo li da se radi o odrasloj i samostalnoj osobi, nedopustiv).

Ovaj se rad sastoji od četiri dijela. U prvom se detaljno obrazlaže prigovor nekonzistentnosti koji neki teoretičari upućuju Millu - prijedlog višestrukog prava glasa vođen je paternalističkim idejama i nije u skladu s antipaternalističkim stavovima koje Mill inače zastupa. Prijedlog prema kojemu bi bolje educirani članovi političke zajednice imali veći politički utjecaj, Mill, prema tumačenju ovih kritičara, opravdava zaštitom manjinskih grupa, ali i edukativnom ulogom koju država treba imati. Smanjenje kolektivnoga suvereniteta političke zajednice, tako da se odlučivanje demokratske većine ograniči većim političkim utjecajem dobro educirane manjine u svrhu educiranja većine ili donošenja kvalitetnih političkih odluka za cijelu zajednicu, svakako izgleda kao oblik paternalizma. Kako bi se ovim radom pokazalo da Millovo opravdanje višestrukoga prava glasa nije izgrađeno na paternalističkim temeljima u nastavku se razjašnjavaju neke njegove ideje vezane uz vrline i uloge dobrog sustava vlasti. U drugom dijelu rada predstavlja se tumačenje prema kojemu je kriterije dobre vlasti moguće svesti na jedan zajednički, temeljni (konsekvencijalistički) kriterij - kvalitetu rezultata koje sustav vlasti proizvodi. Edukativna uloga vlasti, kako se dalje ističe u trećem dijelu, nije ujedno i 
njezin temeljni cilj, već služi kao sredstvo za ostvarenje što boljih posljedica. Prema tome, u ovom se dijelu prihvaća teza da višestruko pravo glasa ima i važnu edukativnu ulogu, ali se negira teza kako je ta uloga paternalistička. Unapređenje moralnih i intelektualnih sposobnosti građana omogućuje nam da kroz demokratske procedure donosimo epistemički najbolje odluke, odnosno stvaramo najbolje rezultate. U završnom, četvrtom dijelu razmatra se kritika prema kojoj je i ovaj zajednički, ujedinjujući kriterij dobre vlasti paternalistički. Čak i ako edukacija građana nije cilj po sebi, nego sredstvo za donošenje kvalitetnih odluka i dobrih posljedica, nije li paternalistički potez ograničiti kolektivni suverenitet ili ga tako urediti da se donose najbolje odluke, čak i protiv volje i bez pristanka većine građana? Ideja normativnog pristanka, prema kojoj u nekim okolnostima pristanak (ali i njegov izostanak) može biti nevažeći, omogućuje nam da kažemo kako u političkom odlučivanju izostanak pristanka većine građana može biti nevažeći - riječ je o slučajevima u kojima se donose odluke koje ne zahvaćaju samo članove većinske grupe, nego i one koji se toj odluci protive, te u kojima postoje jasno prepoznati eksperti. Koristeći ideju normativnoga pristanka, Mill može konzistentno tvrditi kako se princip slobode ne odnosi na političke odluke koje utječu na sve građane, budući da izostanak pristanka u ovim slučajevima nije moralno relevantan. Posljedično, prijedlog višestrukoga prava glasa nije paternalistički i ne krši princip slobode budući da izostanak pristanka na tako donesene odluke nije moralno relevantan.

Cilj ovog rada nije zaključiti raspravu i dati jednu ispravnu interpretaciju Millove političke misli, već predstaviti čitanje koje brani konzistentnost njegovih teza uz korištenje ideja i argumentativnih strategija suvremenih filozofa (poput ideje normativnoga pristanka). Rad počiva na ideji kako su suvremene ideje koje se koriste kako bi pokazale konzistentnost Millovog projekta barem djelomično formulirane i prihvaćene već od samoga Milla, koji ih nije dalje razvijao kao relevantne filozofske termine, ali ih je indirektno izrazio kroz svoje brojne radove.

I.

Antipaternalizam se često ističe kao jedna od glavnih osobina političke filozofije Johna Stuarta Milla (Baccarini 2013; Estlund 2003; Feinberg 1989; Hudlin 1985). Česti prigovori nekonzistentnosti unutar Millove moralne i političke filozofije vezani su uz sukobe između antipaternalizma i utilitarizma (Ten 1980; Primorac 1986; Cressati 1988, prema Baccarini 2013; Cohen-Almagor 2012), odnosno sukobe između antipaternalizma i Millove političke ekonomije (Claeys 2013). Ti sukobi, iako izrazito značajni za ukupnu raspravu, nisu predmet ovog rada. Umjesto njih, fokus je 
POLITIČKE PERSPEKTIVE

ČLANCI I STUDIJE

postavljen na sukob između antipaternalizma i paternalističkog opravdanja višestrukoga prava glasa (Arneson 1982).

Iako ga eksplicitno ne definira, Mill na antipaternalizam gleda kao na doktrinu prema kojoj je (gotovo) uvijek neopravdano ograničavati slobodu odraslih i mentalno zdravih pojedinaca, te takva ograničenja opravdavati brigom za dobrobit samih pojedinaca, čija se sloboda ograničava. Pojedince ne smijemo ograničavati kada izvršavaju radnje koje utječu samo na njih, čak ni onda kada radnje opravdavaju ili čine iz (epistemički ili moralno) pogrešnih razloga ili svojim radnjama štete sebi. Slobodu pojedinca je, doduše, moguće ograničiti kada njegova djelovanja indirektno (a ne samo direktno) utječu i na druge. Čest primjer je slučaj kada djelovanje ili izražavanje pojedinca indirektno šteti drugima, primjerice tako što vrijeđa njihove moralne, religijske ili čak estetske vrijednosti, stvarajući kod drugih negativne osjećaje poput tuge, razočaranja i ljutnje, te umanjujući količinu sreće drugih. Ovaj je primjer već dobro raspravljen u filozofskoj literaturi (Anschutz 1969; Baccarini 1993; Berger 1984; Gaus 2009; Gray 1983), a bitno je uočiti i kako Mill (2008) činjenje štete preko vrijeđanja nečijih religijskih, moralnih ili estetskih osjećaja ne smatra relevantnim razlogom za ograničavanje slobode pojedinaca. Bolji primjeri, u kojima sloboda jednog pojedinca može indirektno nanositi štetu drugima, bili bi slučajevi u kojima se pojedinac zbog radnji koje direktno utječu samo na njega, dovodi u stanje u kojem neće moći izvršiti neku svoju ranije prihvaćenu obavezu. Mill tako navodi primjer roditelja koji zbog prekomjernog konzumiranja alkohola gubi sposobnost skrbiti za svoje dijete, ili primjer policijskog službenika koji iz istog razloga gubi sposobnost adekvatno obavljati svoju javnu funkciju. Ovo su, uz rijetke primjere ugovora kojima se pojedinci trajno odriču slobode, jedini izuzeci u kojima država može intervenirati u slobodu pojedinca koji svojim djelovanjem ne šteti drugim građanima. ${ }^{4}$ Primjeri s kršenjem jasne obaveze koju pojedinac ima prema

4 Još jedan zanimljiv primjer predstavlja Millov (20o8) slučaj s nesigurnim mostom preko kojeg pojedinac želi prijeći, ne znajući koje opasnosti to nosi sa sobom. Millova ideja kako ovog pojedinca možemo spriječiti u prelaženju mosta također predstavlja izuzetak njegovom antipaternalističkom načelu štete, ali bitno je uočiti kako je ovdje riječ samo o privremenoj mjeri - sloboda pojedinca se ograničava samo privremeno, i opravdana je činjenicom da pojedinac, u trenutku kada je želio izvršiti neku radnju, nije imao pristup relevantnim informacijama, odnosno nije bio svjestan mogućih posljedica činjenja te radnje, a mogućnost da ga se na njih upozori bez ograničavanja njegove slobode nije postojala. Slično je, smatra Mill, opravdano postupiti i kada se pojedinac nalazi u stanjima smanjene uračunljivosti, no u oba slučaja riječ je o privremenom ograničavanju slobode koje ne bi bilo opravdano da se pojedinac nalazi u normalnim epistemičkim okolnostima. S druge strane, slučajevi ograničavanja slobode pojedinca oko radnji koje ga čine nesposobnim izvršiti neku jasnu dužnost ostaju opravdani čak i kada je pojedinac odluku o vršenju te radnje donio u epistemički povoljnim okolnostima. 
IVAN CEROVAC

ANTIPATERNALIZAM I VIŠESTRUKO PRAVO GLASA U

MILLOVOJ POLITIČKOJ FILOZOFIJI

drugima izrazito su važni za ovaj rad i bit će detaljnije obrađeni u njegovome završnome dijelu.

Autori koji Milla prozivaju zbog nekonzistentnosti između antipaternalizma u O slobodi i paternalizma u Razmišljanjima o predstavničkoj vlasti (Arneson 1982; Brink 2013) uočavaju kako se, kada govori o kolektivnom suverenitetu, britanski filozof ne libi postaviti snažna ograničenja na doseg legitimnosti većinskih odluka, kao i na samu demokratsku proceduru kojom se one donose. Predlažući složenu podjelu vlasti i dajući parlamentu prvenstveno deliberativnu ulogu, Mill različitim mehanizmima odvaja procese odlučivanja od samih građana, te snažnu ulogu u procesu donošenja političkih odluka daje stručnjacima (Mill 1977a; 1977b; ali i Garforth 1980; Ravlić 2001; Estlund 2003; Baccarini i Ivanković 2015; Cerovac 2016a). Njegovo odbacivanje delegatskog i zagovaranje predstavničkog sustava, prema kojemu zastupnici u parlamentu nemaju dužnost braniti mišljenje građana koji su ih izabrali, te prema kojem građani nemaju mogućnost opozivati svoje zastupnike dok im ne istekne mandat, primjer je jednog od mehanizama kojima se ograničava kolektivni suverenitet. Drugi mehanizmi uključuju postavljanje isključivo deliberativne funkcije parlamenta, koji ne sastavlja zakone i ne donosi odluke, već samo o njima raspravlja i usvaja ih, te prebacivanje izvršne vlasti na vladu koju čine stručnjaci, dok nacrte zakona u suradnji s vladom pišu manje ekspertne skupine. Završno, Millov prijedlog višestrukoga prava glasa, prema kojemu bolje obrazovani i kvalificiraniji građani dobivaju veći politički utjecaj, također predstavlja mehanizam kojime se ograničava kolektivni suverenitet - izrazito kvalificirana manjina na ovaj način može nadglasati neobrazovanu većinu, ili barem otežati ili onemogućiti većini da donosi političke odluke koje bi lako bile usvojene da je izborni sustav organiziran prema načelu jedan građanin-jedan glas. ${ }^{5}$ Ovi mehanizmi oblikuju procedure donošenja odluka, udaljavajući ih od direktnog utjecaja građana (osim na lokalnoj razini), a Mill ih jasno zagovara kada piše kako „preporuča oblik demokracije koji suzbija nagle impulse narodne volje pomoću odugovlačenja, te rigoroznih i formalnih procedura" (Mill 1977c: 189). Prema tome, izgleda da je Millu cilj ograničiti kolektivni suverenitet i oblikovati procedure donošenja odluka kako bi osigurale da stručnjaci imaju što veći utjecaj, ili barem kako bi osigurale da nekvalificirana većina ne može donositi odluke bez pristanka kvalificirane manjine. Arneson (1982) i Brink (2013) smatraju kako je ovo jasan paternalistički kriterij. Milla smatraju nekonzistentnim budući da čvrsto brani individualni suverenitet, koji je ugrožen ako ogra-

5 Millov prijedlog višestrukoga prava glasa odnosi se na izbor političkih predstavnika, ne na proces donošenja konkretnih odluka. U ovom je slučaju primjer namjerno pojednostavljen kako bi se lakše naglasile moguće posljedice nejednake distribucije političkog utjecaja na kolektivni suverenitet. 
ničavamo slobodu pojedinca za njegovo dobro, a zanemaruje kolektivni suverenitet, kojega ugrožava Millov zahtjev da, umjesto većine građana, zakone i odluke donosi mala skupina stručnjaka.

Kako bismo mogli adekvatno proučiti postoji li nekonzistentnost između tih stavova, potrebno je prvo ukratko proučiti Millove kriterije dobre vlasti i ulogu višestrukoga prava glasa. Potrebno je vidjeti zašto Mill smatra da su složene političke procedure, u kojima je narod donekle odvojen od samog procesa odlučivanja, dok u njemu stručnjaci igraju značajnu ulogu, dobar oblik vlasti.

\section{II.}

U Razmišljanjima o predstavničkoj vlasti Mill navodi dva glavna kriterija prema kojima evaluiramo kvalitetu različitih oblika vlasti. Kao najbolji oblik vlasti Mill (1977a) tako uzima onaj koji (i) najbolje unapređuje vrlinu i inteligenciju građana nad kojima se vrši, te koji (ii) organizira postojeće vrline i dobre kvalitete građana na način koji najbolje promiče dugoročno opće dobro. Ovaj rad počiva na ideji kako iza dva kriterija dobre vlasti postoji i jedan manje naglašeni, objedinjujući konsekvencijalistički kriterij - najbolji oblik vlasti je onaj koji stvara najbolje posljedice (Sandel 2009; Peter 2014; Wolff 2016; Cerovac 2016a). Prema tome, ranija dva kriterija služe kao sredstva (što, naravno, ne znači da nemaju i neinstrumentalnu vrijednost) za postizanje željenog cilja - oblika vlasti koji će donositi moralno i epistemički najbolje odluke, odnosno koji će imati najbolje posljedice. Mill jasno potvrđuje ovu ideju kada piše kako je „najbolji oblik vlasti [...] onaj kojeg [...] prati najveća količina dobrih posljedica, sadašnjih i budućih“ (Mill 1977a: 404).

Političke odluke (ili posljedice nekog oblika vlasti) su ispravne ili neispravne (dobre ili loše) neovisno o samoj proceduri ili obliku vlasti koji su ih proizveli. Prema tome, ne evaluiramo kvalitetu odluka prema proceduri kojom su donesene, nego upravo suprotno, kvalitetu procedure evaluiramo prema njezinoj sposobnosti da proizvodi ispravne odluke, odnosno dovodi do dobrih posljedica. Mill daje instrumentalno opravdanje demokracije (Peter 2014; Cerovac 2016a), polazeći od ideje kako je najbolji oblik vlasti onaj koji stvara najveću moguću količinu dobrih posljedica, te nastavljajući kako je upravo demokracija taj oblik vlasti koji stvara najviše dobrih posljedica. Ova se argumentativna strategija najbolje uočava kada razmotrimo Millovu kritiku vlasti dobronamjernog despota (Mill 1977a), vladara koji samostalno donosi sve odluke, ali pri tome nastoji da odluke budu u korist cijele zajednice. Mill smatra kako dobronamjerni vladar neće moći percipirati probleme i adekvatno unapređivati interese različitih društvenih grupa, zbog čega predstavlja gori oblik vlasti od demokra- 
IVAN CEROVAC

ANTIPATERNALIZAM I VIŠESTRUKO PRAVO GLASA U

MILLOVOJ POLITIČKOJ FILOZOFIJI

cije. ${ }^{6}$ Razlika između ova dva oblika vlasti je, prema tome, kontingentna i instrumentalna - demokraciju smatramo boljim oblikom vlasti budući da su posljedice koje proizvodi ovaj tip odlučivanja u konačnici bolje za zajednicu. $^{7}$

\section{III.}

Instrumentalni argument za demokraciju iz prethodnoga dijela možemo sažeti na sljedeći način: političke sustave evaluiramo s obzirom na to u kojoj mjeri unapređuju moralne i intelektualne sposobnosti građana (edukativni kriterij), te u kojoj mjeri organiziraju postojeće kvalitete građana na način koji najbolje promiče dugoročno opće dobro (organizacijski kriterij). Mill pokazuje kako je demokracija oblik vlasti koji najbolje zadovoljava ova dva kriterija. Prema tome, demokracija je najbolji oblik vlasti.

Autori koji Millu zamjeraju paternalizam u opravdanju demokracije ne prigovaraju organizacijskom kriteriju, no smatraju da je edukativni kriterij očit primjer paternalizma. Ne možemo od vlasti tražiti da unapređuje moralne i intelektualne sposobnosti svojih građana, a da pri tome nismo paternalisti (Arneson 1982). „[...] Mill prihvaća drugi, jasno paternalistički razlog; Mill naglašava svoju privrženost ideji da je oblik vlasti odgovoran za obrazovanje i unapređenje građana nad kojima se proteže. [...] Možemo se složiti s Millom kako je vlast dužna nadzirati obrazovanje djece, te da bi vlast trebala obrazovanje učiniti dostupnim svim odraslim građanima. Ali osim ovog, zašto bi vlast bila zadužena za moralno unapređenje odraslih građana?" (Arneson 1982: 48) Uzmemo li Millov edukativni kriterij dobre vlasti kao samostojeći ne-instrumentalni kriterij, onaj koji upućuje na intrinzičnu kvalitetu nekog oblika vlasti, Arnesonov

6 Uz ovaj problem prepoznavanja i promicanja interesa, Mill (1977a; također Ravlić 2001) uočava dva dodatna problema koja benevolentni despot povlači: ukoliko jedna osoba odlučuje o svemu, drugi će građani postati pasivni i neće moći razvijati svoje intelektualne i moralne vrline, ali isto tako neće ni postojati mehanizam kontrole koji bi spriječio mogućnost da benevolentni despot postane malevolentan. Demokracija i kod izbjegavanja ovih problema pokazuje svoju instrumentalnu vrijednost - ona omogućuje i podupire aktivnu participaciju građana, ali i daje narodu određenu kontrolu nad procesom donošenja odluka.

7 Korisno je uočiti još jedan element koji ukazuje na instrumentalnu strukturu Millovog argumenta. On ne tvrdi kako je demokracija bezuvjetno najbolji oblik vlasti, neovisno o okolnostima u kojima se provodi i ljudima koji sudjeluju u procesima odlučivanja i nad kojima se demokratska vlast vrši. Mill tvrdi kako je za necivilizirane i barbarske narode neki oblik prosvjećenog apsolutizma puno bolji oblik vlasti od demokracije - dok građani ne razviju neke temeljne sposobnosti i kompetencije demokratska će im vlast više štetiti nego koristiti (Mill 1977a). Ovo pokazuje instrumentalnu vrijednost i opravdanje demokracije - dok će za neke grupe ljudi demokracija biti najbolji oblik vlasti (dovoditi do najboljih posljedica), za neke će druge grupe biti bolja vlast prosvijećenog apsolutista (Cerovac 2016a). 
POLITIČKE PERSPEKTIVE

ČLANCI I STUDIJE

zaključak je teško izbjeći. ${ }^{8}$ Međutim, raniji dio ovog rada pokazuje kako bi Millova dva kriterija dobre vlasti trebali gledati kao sredstva za zadovoljenje konačnog konsekvencijalističkog kriterija - stvaranje dobrih posljedica za cijelu političku zajednicu. Ako želimo imati političku zajednicu koja donosi najbolje odluke i stvara najbolje političke rezultate, želimo da oni koji sudjeluju u odlučivanju budu dobro obrazovani (edukativni kriterij) i da u procesima odlučivanja budu organizirani na najbolji mogući način, kako bi njihove kompetencije najbolje doprinosile procesu stvaranja kvalitetnih odluka (organizacijski kriterij). Obrazovanje i unapređenje moralnih i intelektualnih sposobnosti građana, prema tome, nije konačan cilj, već bitno sredstvo za stvaranje najboljih političkih odluka i dovođenje do najboljih rezultata.

Može li se ovim instrumentalističkim čitanjem izbjeći prigovor paternalizma? Na individualnoj razini to je teško zamislivo - ako nas država prisiljava na obrazovanje i samousavršavanje kako bi mogli donositi što bolje odluke koje se tiču nas samih, onda i dalje možemo govoriti o jasnom paternalističkom opravdanju. Država ne smije ograničavati slobodu pojedinca kada donosi odluke i izvršava radnje koje utječu samo na njega (Mill 2008). Međutim, demokratsko političko djelovanje pojedinca koji sudjeluje u procesima odlučivanja ne utječe samo na njega - utječe na sve pojedince koji sudjeluju u procesu odlučivanja, kao i na pojedince koji u procesu ne sudjeluju (primjerice politički nezainteresirani građani koji ne žele sudjelovati, ali i oni koji su iz procesa odlučivanja isključeni - djeca, građani koji ne posjeduju minimalne razine obrazovanja i građani s mentalnim poteškoćama i poremećajima). Prema tome, sudjelovanje u demokratskom odlučivanju predstavlja oblik djelovanja koje ne utječe samo na pojedinca, nego i na druge oko njega. Kao što je već izloženo u prvom dijelu ovoga rada, Mill smatra legitimnim uplitanje u slobodu pojedinca oko radnji koje se ne tiču samo njega samoga, već i drugih građana, pogotovo kada se radi o radnjama zbog kojih se pojedinac dovodi u stanje u kojem nije u mogućnosti adekvatno ispuniti neku svoju dužnost. Primjerice, država može intervenirati i zabraniti pojedincu konzumaciju alkohola, no to ne smije učiniti iz paternalističkog opravdanja (da bi sačuvala zdravlje samog pojedinca, ili zato što država smatra da je konzumacija alkohola 'niže' zadovoljstvo koje sprječava dolazak do 'viših' zadovoljstava), nego da bi zaštitila one kojima se nanosi šteta zbog nemogućnosti pojedinca da izvrši neku dužnost. Primjerice, država može ograničiti slobodu pojedinca da

8 Edukativni kriterij dobre vlasti je moguće pokušati opravdati pozivanjem na razlikovanje između viših i nižih užitaka (Mill 2002). Vlast ne postiže dobre posljedice samo ukoliko zadovoljava postojeće interese građana, već i ukoliko unapređuje kvalitetu tih interesa (Macpherson 2011). Međutim, nije jasno na koji način ovo objašnjenje izbjegava problem paternalizma. Štoviše, izgleda da samo pojačava paternalističku ulogu vlasti. 
IVAN CEROVAC

ANTIPATERNALIZAM I VIŠESTRUKO PRAVO GLASA U

MILLOVOJ POLITIČKOJ FILOZOFIJI

konzumira alkohol ako ga ta radnja dovodi u stanje u kojem ne može izvršavati neku dužnost koju ima, poput obavljanja policijske dužnosti (ako je riječ o policijskom službeniku) ili brige za djecu (ako je riječ o roditelju ili skrbniku) (Mill 20o8). Usredotočimo li se na primjer brige o djetetu, izgleda da Mill ne bi paternalističkim smatrao ograničenja slobode pojedinca poput zabrane prekomjernog konzumiranja alkohola, ali i regulative koje traže od roditelja (ako se za time pokaže potreba) da prođu neki kraći tečaj brige za dijete. Završno, Mill smatra da, ako roditelj redovito zanemaruje svoju dužnost i time šteti djetetu, država može roditelju oduzeti (a na sebe preuzeti) pravo da odlučuje o pitanjima koja se tiču njihove djece (Mill 20o8). Ovo nisu nelegitimna uplitanja u slobodu pojedinca budući da je riječ o radnjama koje ne štete (samo) tome pojedincu, nego i drugima oko njega. ${ }^{9}$ „Kad god, ukratko, postoji jasna šteta, ili jasna opasnost od štete, bilo [nekom drugom] pojedincu ili zajednici, slučaj se miče iz područja slobode i stavlja u područje moralnosti ili zakona“ (Mill 2008: 153). Povučemo li analogiju između ranijih primjera i kriterija za dodjelu prava glasa u procesima demokratskoga odlučivanja, uočit ćemo bitne sličnosti. Mill smatra opravdanim uskratiti pravo glasa pojedincima koji nisu zadovoljili niti minimalne obrazovne kvalifikacije, kao i onima koji na izbore dolaze u alkoholiziranom stanju (Mill 1977a; također Sturgis 2005). U oba slučaja država ograničava slobode pojedinca, no to ne čini s ciljem zaštite ili promicanja interesa ili dobrobiti samog pojedinca, nego kako bi spriječila da pojedinac svojim djelovanjem nanese štetu drugim građanima (ili se dovede u stanje u kojem neće moći ispunjavati neke jasne dužnosti koje ima prema drugima). Edukativni kriterij dobrog oblika vlasti može, prema tome, biti opravdan bez pozivanja na paternalizam - zakoni, javne politike i odluke mogu naštetiti drugim građanima i zbog toga naše sudjelovanje u procesima odlučivanja (ili u procesima izbora onih koji će odlučivati) ne ulazi u područje neograničene slobode, već u područje moralnosti i zakona. Edukativni kriterij nije uključen zbog nas samih, nego zbog drugih

9 Bitno je uočiti kako ovaj argument nije povezan s raspravom oko ograničavanja slobode pojedinaca zbog mogućnosti da izražavanje te slobode povrijedi moralne, religijske i estetske osjećaje drugih pojedinaca. Mill veoma jasno odgovara na te prigovore u O slobodi, a o njima raspravljaju i brojni drugi teoretičari (Anschutz 1969; Baccarini 1993; Berger 1984; Gaus 2009; Gray 1983). Dok se u ranijim raspravama fokus nalazio na pitanju bi li vrijeđanje nečijih moralnih, religijskih ili estetskih osjećaja trebalo biti zahvaćeno Millovim 'načelom štete' (tj. možemo li ovo vrijeđanje osjećaja smatrati relevantnim oblikom nanošenja štete), sada govorimo o kolektivnim odlukama koje mogu nedvosmisleno i direktno štetiti nekom pojedincu ili grupi pojedinaca. Zakoni i javne politike iz područja klasičnih državnih resora (obrambena politika i politika unutarnje sigurnosti, politika javnog upravljanja i druge), te iz područja gospodarstva i socijalne skrbi utječu na živote građana i mogu im naštetiti na bitno drugačiji način od onoga kako korištenje slobode govora može naštetiti njihovim religijskim, moralnim i estetskim osjećajima. 
POLITIČKE PERSPEKTIVE

ČLANCI I STUDIJE

pojedinaca kojima možemo naštetiti donošenjem loših zakona i pogrešnih javnih politika.

Pitanje na koje ipak nije direktno odgovoreno povezano je s Millovim prijedlogom uvođenja višestrukog prava glasa. Složimo li se da edukativni kriterij dobrog oblika vlasti možemo opravdati i nepaternalistički, ostaje nam problem opravdanja višestrukoga prava glasa. Može li se i ovaj prijedlog opravdati bez pozivanja na paternalizam?

\section{IV.}

Mill uvođenje višestrukoga prava glasa opravdava kroz dva odvojena argumenta. Prvi, zaštitni argument polazi od pretpostavke kako će se uvođenjem višestrukoga prava glasa spriječiti tiranija neobrazovane većine nad obrazovanom manjinom, odnosno promicanje partikularnih interesa kroz demokratsko odlučivanje. U zajednici u kojoj većinu građana čine slabo obrazovani radnici, uvođenje jednakog prava glasa moglo bi lako dovesti do jednostavnog preglašavanja neistomišljenika i donošenja odluka koje štete pripadnicima manjine, ali i cijeloj zajednici. Uvođenje nejednakog prava glasa osigurat će, po Millu, da niti jedna grupa građana ne može samovoljno donositi političke odluke bez da raspravlja i ulazi u kompromise s manjinskim grupama. Drugi, epistemički argument ne nastoji direktno zaštititi manjinske grupe od preglasavanja u demokratskom procesu, već polazi od ideje kako razlike u epistemičkim i moralnim sposobnostima (koje po Millu iščitavamo iz različitih stupnjeva obrazovanja građana, ili iz složenosti poslova koje obavljaju) zahtijevaju nejednaku distribuciju političkoga utjecaja (Mill 1977a). Oba se argumenta treba interpretirati konsekvencijalistički: ukoliko demokratsko odlučivanje postane puko preglasavanje manjine, te ukoliko demokratske procedure ne pronađu način da iskoriste epistemičke sposobnosti manjega broja dobro obrazovanih građana, rezultati tih procedura bit će substantivno loše političke odluke koje će dovesti do loših posljedica za cijelu političku zajednicu. ${ }^{10}$

Teoretičari koji ukazuju na paternalističku argumentaciju u Millovu opravdanju višestrukoga prava glasa problem vide u epistemičkome argumentu: „Možemo ugrubo uzeti [prvi] cilj [zaštitni argument] kao istovjetan cilju sprečavanja kršenja prava manjine i spremno zaključiti kako je ograničavanje slobode većine kako bi se zaštitila manjina jasno nepaternalističko. [Drugi] cilj [epistemički argument], međutim, izgleda jasno paternalistički. Opasnost od koje se njime nastoji zaštititi su loše politike do kojih dolazi kada neobrazovana većina nastoji promicati svoje interese

10 Za više o strogo konsekvencijalističkoj interpretaciji Millove političke filozofije, te o epistemičkom argumentu kojime Mill opravdava uvođenje višestrukog prava glasa videti Estlund (2003), Peter (2014), Wolff (2016) i Cerovac (2016a, 2016b). 
kroz demokratske procese“ (Arneson 1982: 56). Prema ovoj interpretaciji, Mill može ostati dosljedan antipaternalist i zadržati prijedlog višestrukoga prava glasa samo ukoliko odustane od epistemičkoga argumenta i ideje da bi bolje obrazovanje trebalo povlačiti veći politički utjecaj u procesima demokratskog odlučivanja. Međutim, epistemički argument predstavlja bitan dio Millove teorije, pogotovo u njezinom izraženome instrumentalističkom shvaćanju od kojega ovaj rad polazi. Odustati od epistemičkog argumenta Millu je vrlo teško budući da istom daje primarnu ulogu u opravdanju višestrukog prava glasa. Zato Mill piše kako „ne preporuča višestruko pravo glasa kao nešto nepoželjno što se može opravdati i tolerirati kao privremena mjera da bi se spriječilo veće zlo“ (primjerice, klasno zakonodavstvo). Umjesto toga, Mill naglašava kako „na jednako pravo gleda kao na nešto samo relativno dobro, ali u načelu pogrešno, zato što polazi od krivog standarda i ima loš utjecaj na promišljanje glasača" (Mill 1977a: 478). Sasvim je smisleno reći kako Mill uvodi višestruko pravo glasa iz epistemičkih razloga, kako bi osigurao što bolje i ispravnije političke odluke, odnosno što bolje rezultate političkih procesa. Međutim, snažnim oslanjanjem na drugi (epistemički) argument Mill ponovno postaje meta kritičara koji mu zamjeraju uvođenje paternalizma.

Milla možemo pokušati obraniti ističući kako političke odluke utječu na sve građane, tako da višestruko pravo glasa služi kao mehanizam koji štiti prava manjina. Naposljetku, do kršenja prava manjina može doći i bez postojanja sebičnih interesa većine - prava manjine može kršiti i dobronamjerna, ali neobrazovana i nekvalificirana većina koja donosi loše zakone i javne politike. Mill i sam piše da: „Nema nikakvog razloga da primijenimo ovu doktrinu [o nejednakom političkom utjecaju] na slučajeve koji se mogu smatrati individualnim i privatnim stvarima pojedinca. U slučajevima koji se tiču samo jedne od dvije osobe, ta je osoba slobodna slijediti svoje mišljenje, neovisno o tome koliko je druga osoba mudrija od nje. Ali što kada govorimo o stvarima koje se jednako tiču obje osobe: kada, ukoliko neznalica ne odustane od svog mišljenja, mudrac mora odustati od svoga? Koji je od modela odlučivanja u najboljem interesu obje osobe, te najprikladniji općenito?" (Mill 1977a: 474) U slučajevima u kojima se odluke tiču samo jedne osobe, ta osoba ima puni autoritet da ih donosi neovisno o mišljenju drugih. Međutim, u slučajevima u kojima se odluke odnose na više osoba, među kojima postoji neslaganje oko toga što je najbolje učiniti, kao i razlike u stupnju obrazovanja, Mill smatra kako se odlučivanje ne može svesti na jednostavnu proceduru obilježenu načelom jedna osoba-jedan glas. Kada trebamo donijeti odluku koja jednako utječe na sve i ne možemo izbjeći scenarij u kojem će barem neki građani biti prisiljeni prihvatiti odluku s kojom se ne slažu, Mill smatra kako različiti stupnjevi epistemičke kvalificiranosti građana povlače različite razine političkog utje- 
POLITIČKE PERSPEKTIVE

ČLANCI I STUDIJE

caja. Ako već ne možemo izbjeći da netko bude prisiljen prihvatiti odluku s kojom se ne slaže, onda bolje da se prisila vrši nad onima manje kvalificiranima (čak i ako ih brojčano ima umjereno više) nego nad onima više kvalificiranima (čak i ako ih ima brojčano umjereno manje).

Kritičari ovu ideju smatraju dubinski pogrešnom. Upravo iz nje izvire paternalizam zbog kojega se Milla proziva. „Ako se nečiji izbor mora odbaciti, [...] manje je paternalistički kada većina vrši prisilu nad manjinom nego kad manjina vrši prisilu nad većinom. Drugim riječima, ako je paternalizam loš, onda je više paternalizma gore, a manje paternalizma bolje. Kako god da definirali prisilu, možemo tvrditi da ima više prisile nad odraslim osobama, protiv njihove volje i za njihovo dobro, kada manji broj stručnjaka ima moć da izglasa javnu politiku koju smatraju korisnom za sve, uključujući i većinu građana koji se s njom ne slažu, nego kad većina građana ima moć izglasati javnu politiku koja se također smatra korisnom za sve, uključujući i manji broj stručnjaka koji se s njom ne slažu“" (Arneson 1982: 58).

Arnesonova je glavna teza kako više prisile (za opće dobro) znači i više paternalizma. Budući da će više ljudi biti prisiljeno prihvatiti odluku s kojom se ne slažu ${ }^{11} u$ slučajevima kada je ona donesena procesom koji veći politički utjecaj daje manjini, Mill zagovaranjem višestrukog prava glasa zagovara određeni oblik paternalizma. Ukoliko želimo izbjeći paternalizam, odnosno ukoliko ga želimo svesti na najmanju moguću razinu, podržavat ćemo sustav s najmanje prisile (sustav u kojem je najmanji broj ljudi prisiljen prihvatiti odluku s kojom se ne slaže), a to je sustav koji zagovara jednaki politički utjecaj za sve građane (Arneson 1982). Svaka nejednaka distribucija političkog utjecaja (pa tako i Millov prijedlog višestrukog prava glasa) otvara mogućnost scenariju u kojem je veći broj ljudi prisiljen prihvatiti odluke s kojima se ne slaže nego što je to minimalno potrebno. Kritičari zaključuju kako ovo mora biti oblik paternalizma budući da se pozivanjem na epistemički kriterij (ispravnost odluka i kvaliteta posljedica) opravdava vršenje prisile nad većim brojem građana nego što bi bio slučaj kada bi svi građani imali jednaki politički utjecaj.

Iako je riječ o zanimljivome prigovoru, zadnji dio ovog rada dovodi u pitanje može li se ovaj prigovor uputiti Millovoj političkoj misli. U ranijim je dijelovima naglašeno kako Mill ne smatra svaki oblik ograničavanja slobode pojedinca neopravdanim. Možemo ograničiti slobodu pojedinca kada nanosi štetu drugima oko sebe, kao i kada (zbog prakticiranja te slobode) ne uspijeva izvršiti neku jasno pripisivu dužnost. Ove intervencije u slobodu pojedinca ne smatramo paternalističkima budući da ih ne

11 Pretpostavljamo da nije riječ o odlučivanju o pravima i slobodama manjina, nego o političkom odlučivanju kojim se stvaraju zakoni i javne politike usklađene sa sustavom liberalnih prava. 


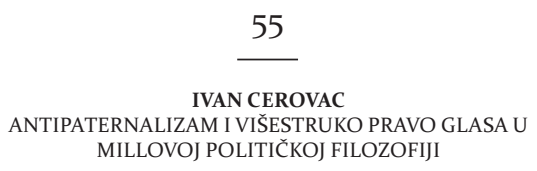

opravdavamo pozivanjem na dobrobit samog pojedinca, nego na štetu koju svojim djelovanjem pojedinac nanosi drugim pojedincima ili cijeloj zajednici. Može li se jednaka distribucija političkoga utjecaja dovesti u pitanje zbog potencijalne štete koju ovaj sustav donošenja odluka može nanijeti dobro obrazovanoj manjini? Možemo li reći da posjedovanjem i korištenjem jednakog političkog utjecaja neobrazovani građani krše neku od dužnosti koje imaju?

Ako Mill želi zadržati višestruko pravo glasa utemeljeno na epistemičkome (a ne samo na zaštitnome) argumentu, morat će potvrdno odgovoriti na barem jedno od dva ranija pitanja. U tome će mu značajno pomoći poznati koncept 'normativnoga pristanka' na politički autoritet (Estlund 2008).

Opće je prihvaćena teza kako pristanak koji osoba daje ponekad može biti nevaljan. Iz takvog pristanka ne slijede moralne dužnosti i prava koja bi slijedila iz valjanog pristanka. Primjerice, možemo se podvrgnuti autoritetu i pristati služiti osobu koja nam je zaprijetila vatrenim oružjem, no to ne znači da osoba ima moralno pravo zapovjedati nam niti da mi imamo moralnu dužnost slušati tu osobu. U tome je slučaju, kao i u nizu sličnih, naš pristanak nevaljan, i osoba koja nam je prijetila ne može se pozivati na moralnu dužnost koju imamo zato što smo ranije pristali. Međutim, i odbijanje pristanka ponekad može biti nevaljano. ${ }^{12}$ Ukoliko se pred nama odvila teška prometna nesreća u kojoj ima ozlijeđenih, imamo moralnu dužnost pomoći im. Ukoliko je na poprištu nesreće prisutan liječnik (te nemamo razloga sumnjati u njegove kompetencije), imamo moralnu dužnost slijediti njegove upute, budući da znamo kako je to najbolji način da ispunimo svoju dužnost prema ozlijeđenima. Mi možemo odbiti liječnikov autoritet, ali izgleda da postoji nešto moralno problematično u tom činu. U ovom slučaju naše odbijanje pristanka je nevaljano. Za nas bi ne pristati na liječnikov autoritet bilo nemoralno budući da tim činom odbacujemo najbolje sredstvo za izvršenje naše dužnosti prema ozlijeđenima.

Postoji bitna razlika između nevaljanosti pristanka na autoritet liječnika u slučaju prometne nesreće, u kojoj su ozlijeđeni drugi građani, i u slučaju koji je vezan samo uz nas same. Iako je liječnik daleko kompetentniji od

12 Estlund pruža poznati primjer s čišćenjem garaže. Ukoliko je Alf u više navrata pomogao Betty očistiti njezinu garažu i prihvatio njezin autoritet prilikom čišćenja, izgleda da Betty ima moralnu dužnost pomoći Alfu u čišćenju njegove garaže kada on to zatraži, te prihvatiti u jednakoj mjeri njegov autoritet. Ukoliko Betty odbije prihvatiti čišćenje garaže i ne prihvati Alfov autoritet, možemo tvrditi da je Bettyn izostanak pristanka nevaljan. Ona i dalje ima moralnu dužnost pomoći Alfu (i prihvatiti njegov autoritet prilikom čišćenja garaže), i činjenica da nije dala stvarni pristanak ne umanjuje njezinu dužnost, pa tako ni Alfov autoritet. Naravno, ovo ne implicira da Alf ima legitimitet natjerati Betty na čišćenje garaže, ali i dalje ostaje da Betty krši neku moralnu dužnost koju ima prema Alfu. Za detaljnije objašnjenje normativnog pristanka videti Estlund (2005) i Estlund (2008). 
POLITIČKE PERSPEKTIVE

ČLANCI I STUDIJE

mene za donošenje ispravnih odluka o mom zdravlju, puka kompetencija ne daje mu nikakav autoritet nad mnom. Ovo je primjer koji je lako povezati s Millovom argumentacijom u $O$ slobodi. Čak i ako su drugi stručniji od nas, oni ne mogu imati autoritet nad nama kada govorimo o stvarima koje se tiču samo nas. ${ }^{13}$ Ukoliko odbijam svoje liječenje od neke nezarazne bolesti (rak, kardiovaskularne bolesti, dijabetes) i pri tome ne predstavljam opasnost za druge, nemam moralnu dužnost prihvatiti autoritet liječnika (iako bi to bilo prudencijalno). Međutim, ukoliko se nalazim na poprištu nesreće i način mog postupanja će utjecati na druge, slično kao u demokratskom odlučivanju u Razmišljanjima o predstavničkoj vlasti, imam jasnu dužnost pomoći ozlijeđenima. U tom je slučaju za mene moralno pogrešno odbaciti autoritet liječnika - moje bi nedavanje pristanka u ovom slučaju bilo nevaljano.

Prema tome, ukoliko osoba ima neku moralnu dužnost, stručnjak može imati legitimni autoritet nad tom osobom budući da samo slijedeći njegove upute osoba može ispuniti svoju dužnost. No možemo li tvrditi da prilikom sudjelovanja u procesima političkog odlučivanja imamo neku jasnu dužnost prema drugima koji će biti zahvaćeni odlukom koju donesemo? Ukoliko takva dužnost postoji, Millov epistemički argument za uvođenje višestrukog prava glasa neće biti paternalističke naravi. Naime, uvođenje nejednake distribucije političkog utjecaja (i prisiljavanje većine da prihvati odluku manjine, kako bi problem postavio Arneson) opravdat ćemo pozivanjem na neku dužnost koju imaju svi građani, bili oni pripadnici većinske ili manjinske grupe.

Mill nigdje nije eksplicitno napisao o kojoj je dužnosti riječ, no može se zaključiti, kako Mill smatra, da, kada donosimo odluke koje se tiču i drugih, imamo jasnu moralnu dužnost koristiti epistemički najbolje procedure donošenja odluka. ${ }^{14}$ Mill pri tome ne smatra da je vladavina male skupine stručnjaka epistemički najbolja procedura za donošenje odluka, kao što ne smatra ni da će potpuno jednaka distribucija političkog utjecaja dovesti do epistemički najboljih rezultata. ${ }^{15}$ Umjesto toga, predlaže

13 Riječ je o poznatoj 'stručnjak-šef grešci' koju uvodi Estlund (20o8), a njezine implikacije kvalitetno obrađuju (dolazeći do bitno različitih zaključaka) Zelić (2012) i Brennan (2017).

14 Isto vrijedi i za opravdanje naše dužnosti da slušamo upute liječnika kada pokušavamo spasiti ozlijeđene u nesreći. Mi imamo dužnost slijediti proceduru donošenja odluka za koju možemo očekivati da će najbolje dovesti do ispunjenja naše dužnosti prema ozlijeđenima. Slušanje uputa liječnika je procedura donošenja odluka kojom bolje ispunjavamo našu dužnost, svakako bolje nego da odluke donosimo sami ili da ih donosimo demokratski, u uvjetima potpune jednakosti političkog utjecaja.

15 James Mill (2015) i Jeremy Bentham (1988) kreću od ideje kako je egalitarno-demokratska procedura odlučivanja ujedno i ona u kojoj će biti zadovoljeni interesi najvećeg broja građana i izbjegnuto promicanje 'mračnog interesa' vlastodržaca. Mill (1977a) se ne slaže: većina može biti u krivu oko svog dugoročnog interesa (što naglašava Anschutz 1969), no kada bi stao na 


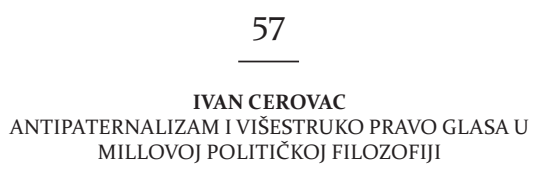

miješani sustav u kojemu će politički utjecaj biti nejednako distribuiran, tako da politički sustav istovremeno uzima u obzir mišljenja svih građana (uvažava epistemičku vrijednost različitih perspektiva), ali i daje veću ulogu u odlučivanju onima bolje obrazovanima (uvažava epistemičku vrijednost stručnjaka).

Ovaj miješani sustav donošenja odluka treba, prema Millu, imati epistemičke kvalitete koje svi građani mogu percipirati. Drugim riječima, kao i u slučaju normativnog pristanka na autoritet liječnika kada pomažemo ozlijeđenoj osobi u prometnoj nesreći, stručnost koja dokida egalitarnu distribuciju političkog utjecaja, kao i epistemička kvaliteta same procedure, moraju biti javno dostupni i shvatljivi svim građanima. Samo tako ideja normativnog pristanka može imati dovoljnu snagu da opravda prijedlog višestrukog prava glasa. Mill je ovdje dosta jasan: „Nužno je da ovaj veći [politički] utjecaj bude dodijeljen na temeljima koje svi mogu razumjeti, i koje svi percipiraju kao pravedne“ (Mill 1977a: 474); , [Razlike u glasačkoj moći] nisu donesene arbitrarno, nego su takve da ih mogu shvatiti i prihvatiti svi opće savjesti i razumijevanja. Utemeljene su tako da ne budu nužno odbojne ničijem shvaćanju pravednosti“ (Mill 1977a: 476). Mill je uvjeren kako razina stečenog obrazovanja i složenost poslova koje netko obavlja predstavljaju temelje za dodjelu nejednakog političkog utjecaja koje svi mogu vidjeti kao pravedne. Naravno, možemo ovo uvjerenje dovesti u pitanje, no to ne mijenja činjenicu da je Mill vjerovao kako postoji javno opravdanje nejednake distribucije političke moći, na kojem počiva i ideja normativnog pristanka. Ako svi mogu vidjeti neku proceduru donošenja odluka kao epistemički najkvalitetniju, kada provodimo zakone i odluke koje ograničavaju slobodu nekih pojedinaca (koji se s tim odlukama sadržajno ne slažu) dužni smo, onda, biti sigurni da su te odluke donesene epistemički najboljom dostupnom procedurom. Protivljenje (nedavanje pristanka) onih koji se ne slažu s rezultatima takve procedure nevaljano je. To, naravno, ne znači da oni moraju odustati od svog vjerovanja (kao što bi tražio Rousseau), nego samo da moraju prihvatiti politički autoritet tako donesene odluke.

Ovim se radom ne tvrdi kako je Millov model demokracije, obilježen prijedlogom višestrukoga prava glasa, ujedno i epistemički najbolji oblik donošenja odluka. ${ }^{16}$ Dovoljno je ustvrditi kako ga je Mill takvim smatrao.

ovome J. S. Mill bi uistinu bio paternalist. Međutim, budući da većina donosi zakone i odluke koji utječu na i ograničavaju slobodu manjine, slučaj je bitno drugačiji. Ukoliko će doći do ograničavanja slobode, bitno je da do toga dođe na temelju epistemički najpouzdanije procedure. Za razliku od Benthama i svog oca, Mill ne smatra da demokracija obilježena univerzalnim i jednakim pravom glasa ima tu instrumentalnu epistemičku vrijednost.

16 Štoviše, većina zastupnika epistemičke demokracije smatra kako se prijedlog višestrukog prava glasa može odbaciti na epistemičkim temeljima. Za detaljniju argumentaciju videti Estlund (2003. i 2008). 
POLITIČKE PERSPEKTIVE

ČLANCI I STUDIJE

Naime, ako građani imaju dužnost koristiti epistemički najbolju proceduru kada donose političke odluke koje utječu i na druge (koji se s tim odlukama ne slažu), te ako je demokracija obilježena višestrukim pravom glasa najbolja procedura donošenja odluka, onda, prigovor paternalizma postaje isprazan. Mill je možda bio u krivu oko epistemičkih vrlina prijedloga višestrukog prava glasa, ali i dalje stoji da opravdanje ovog prijedloga nije utemeljeno u paternalističkim idejama, već na dužnosti koju imamo prema drugima kada donosimo odluke koje na njih utječu (ograničavaju njihovu slobodu) i s kojima se oni ne slažu.

\section{V.}

Ovaj rad zaključujem pregledom nekoliko temeljnih ideja koje pokazuju zašto Millov prijedlog višestrukoga prava glasa, odnosno nejednaka distribucija političkog utjecaja koju zagovara u Razmišljanjima o predstavničkoj vlasti, nije u sukobu s antipaternalizmom koji Mill zagovara u O slobodi. (i) Mill smatra kako je demokracija obilježena višestrukim pravom glasa epistemički i instrumentalno najbolja procedura odlučivanja. Ona najbolje zadovoljava dva kriterija dobre vlasti, te u konačnici dovodi do najboljih političkih odluka i najboljih rezultata. (ii) Kada donosimo političke odluke koje će, osim na nas, utjecati i na druge (koji se sa sadržajem tih odluka ne slažu) imamo dužnost koristiti epistemički najbolju proceduru među dostupnim procedurama odlučivanja, te prihvatiti rezultate koje takva procedura proizvodi. (iii) Budući da imamo dužnost prihvatiti epistemički najbolju proceduru (i njezine rezultate) kada donosimo odluke koje utječu i na druge (koji se s njima ne slažu), ona je podržana našim normativnim pristankom (bilo bi nemoralno ne prihvatiti je). (iv) Budući da je procedura prihvaćena (i opravdana) normativnim pristankom utemeljenim u našim dužnostima prema drugima, ona ne mora biti opravdana na paternalističkim temeljima. Prema tome, nema sukoba između Millove političke misli u Razmišljanjima o predstavničkoj vlasti i O slobodi. Mill u oba dijela ostaje vjeran antipaternalističkim idejama po kojima je toliko poznat.

\section{LITERATURA}

Anschutz, R. P. 1969. The Philosophy of J. S. Mill. Oxford: Clarendon Press.

Arneson, R. 1982. "Democracy and Liberty in Mill's Theory of Government". Journal of the History of Philosophy 20 (1): 43-64.

Baccarini, E. 1993. Sloboda, demokracija, pravednost: Filozofija politike J. S. Milla. Rijeka: Hrvatski kulturni dom.

Baccarini, E. 2013. “John Stuart Mill”. U Kulenović, E. (ur.). Moderna politička teorija. (291-330). Zagreb: Fakultet političkih znanosti u Zagrebu. 
IVAN CEROVAC

ANTIPATERNALIZAM I VIŠESTRUKO PRAVO GLASA U

MILLOVOJ POLITIČKOJ FILOZOFIJI

Baccarini, E. and Ivanković, V. 2015. "Mill's Case for Plural Voting and the Need for Balanced Public Decisions”. Prolegomena 14 (2): 137-156.

Bentham, J. 1988. The Principles of Morals and Legislation. London: Prometheus Books.

Berger, F. R. 1984. Happiness, Justice, and Freedom. The Moral and Political Philosophy of John Stuart Mill. Berkeley: University of California Press.

Brennan, J. 2017. Against Democracy. New Jersey: Princeton University Press.

Brink, D. 2013. Mill's Progressive Principles. Oxford: Clarendon.

Cerovac, I. 2016a. "Plural Voting and J. S. Mill's Account of Democratic Legitimacy”. Croatian Journal of Philosophy 16 (46): 91-106.

Cerovac, I. 2016b. “The Role of Experts in a Democratic Society”. Journal of Education, Culture and Society 7 (2): 75-88.

Claeys, G. 2013. Mill and Paternalism. New York: Cambridge University Press.

Cohen-Almagor, R. 2012. "Between Autonomy and State Regulation: J. S. Mill's Elastic Paternalism”. Philosophy 87 (4): 557-582.

Estlund, D. 2003. “Why not Epistocracy?” In Reshotko, N. Desire, Identity and Existence: Essays in Honour of T. M. Penner. New York: Academic Printing \& Pub.

Estlund, D. 2005. "Political Authority and the Tyrany of Non-Consent". Philosophical Issues 15: 351-367.

Estlund, D. 2008. Democratic Authority. New Jersey: Princeton University Press.

Feinberg, J. 1989. The Moral Limits of the Criminal Law: Harm to Self. New York: Oxford University Press.

Garforth, F. W. 1980. Educative Democracy. John Stuart Mill on Education in Society. New York: Oxford University Press.

Gaus, G. 2009. "State Neutrality and Controversial Values in On Liberty". In Ten, C. L. (ed.). Mill's On Liberty. A Critical Guide. New York: Cambridge University Press.

Gray, J. 1983. Mill on Liberty. A Defence. London: Routledge and Kegan Paul.

Hudlin, C. V. 1985. Antipaternalism and John Stuart Mill. A Thesis Submitted in partial fulfilment of the Requirements of University of Oklahoma for the Degree of Doctor of Philosophy. Norman: The University of Oklahoma.

Macpherson, C. B. 2011. The Life and Times of Liberal Democracy. New York: Oxford University Press.

Mill, J. 2015. An Essay on Government. New York: Cambridge University Press.

Mill, J. S. 1977a. Considerations on Representative Government. Toronto: University of Toronto Press. 
Mill, J. S. 1977b. Thoughts on Parliamentary Reform. Toronto: University of Toronto Press.

Mill, J. S. 1977c. Essays on Politics and Society: Part I. Toronto: University of Toronto Press.

Mill, J. S.2002. Utilitarianism. London: Hackett Publishing Company.

Mill, J. S. 2008. On Liberty. Oxford: Oxford University Press.

Peter, F. 2014. "Political Legitimacy”. In Zalta, E. N. (ed.). The Stanford Encyclopedia of Philosophy (Spring 2014 Edition). Stanford University Press.

Primorac, I. 1986. „Millova obrana slobode“. Filozofska istraživanja 16 (2): 549565.

Ravlić, S. 20o1. Poredak slobode: Politička misao Johna Stuarta Milla. Zagreb: Hrvatsko filozofsko društvo.

Sandel, M. J. 2009. Justice: What's the Right Thing to Do? New York: Farrar, Straus and Giroux.

Sturgis, D. 2005. “Is Voting a Private Matter?” The Journal of Social Philosophy 36: 18-30.

Ten, C. L. 1980. Mill on Liberty. Oxford: Clarendon Press.

Wolff, J. 2016. An Introduction to Political Philosophy. New York: Oxford University Press.

Zelić, N. 2012. Ideja javnog uma. Neobjavljena doktorska disertacija. Sveučilište u Rijeci, Hrvatska.

\section{SUMMARY}

\section{Antipaternalism And Plural Voting Proposal In J. S. Mill's Political Philosophy}

The appeal to inconsistency, which is sometimes raised against J. S. Mill's political philosophy, takes various forms, and this paper focuses on the appeal to inconsistency between antipaternalism promoted in On Liberty and paternalistic justification of democracy and plural voting proposal introduced in Considerations on Representative Government. The paper characterizes Mill as a democratic instrumentalist and emphasizes that Mill's justification of educational role of democracy and the epistemic value of plural voting proposal need not be grounded in paternalistic ideas. By combining Mill's claim that the government can intervene and limit the freedom of an individual when she is performing an action by which a distinctive duty she has towards others is violated with Estlund's idea of political justification through normative consent, the paper shows that Mill's justification of democracy (and of plural voting proposal) can be grounded in duties we have towards others, and not in paternalism.

KEY WORDS: paternalism, plural voting proposal, normative consent, democratic instrumentalism, epistemic democracy, Mill, Arneson, Estlund. 